\title{
ANALISIS KEPUASAN DAN LOYALITAS KONSUMEN TERHADAP PISANG RAJA SEREH DAN PISANG CAVENDISH DI KOTA BANDAR LAMPUNG
}

\author{
(Satisfaction and Consumer Loyalty Analysis to Raja Sereh Banana and Cavendish Banana \\ in Bandar Lampung City)
}

M Hutama Pandu Negara AT, Suriaty Situmorang, Dame Trully Gultom

Jurusan Agribisnis, Fakultas Pertanian, Universitas Lampung, Jl. Prof. Dr. Soemantri Brodjonegoro No.1 Bandar Lampung 35141, e-mail:suriaty.situmorang@fp.unila.ac.id.

\begin{abstract}
The aims of this research are to determine the satisfaction, and loyalty of consumers to Raja Sereh Banana and Cavendish Banana products in Bandar Lampung City. The research is conducted in June to July 2018. The samples are consumers of Raja Sereh Banana and Cavendish Banana that are recruited byaccidental sampling. The number of consumer respondents are 80 people, divided by 40 respondent of Raja Sereh Banana and 40 respondent of Cavendish Banana. This research is conducted in two different locations, namely traditional market (Pasir Gintung Market) and modern market (Gelael Supermarket). The research data is analyzed by descriptive analysis, namely Consumer Satisfaction Index Analysis (CSI) and Loyalty Pyramid. The results of this research showed that Raja Sereh Banana and Cavendish Banana consumers were "satisfied" and "loyal". Consumer satisfaction of Raja Sereh Banana was 74.66 percent and the consumer satisfaction of Cavendish Banana consumer was 71.09 percent. The level of consumer loyalty was classified as a buyer who was committed with a value of 85.00 percent for Raja Sereh Banana and 90.00 percent for Cavendish Banana.
\end{abstract}

Key words:bananas, consumer, loyalty, satisfaction

\section{PENDAHULUAN}

Pisang merupakan komoditas penunjang ketahananan pangan dan berpotensi sebagai komoditas agribisnis serta dibudidayakan di hampir seluruh negara iklim tropis maupun subtropis. Produksi pisang di Indonesia mengalami peningkatan dari tahun 2011 sampai 2015, namun pada tahun 2016 terjadinya penurunan produksi pisang di Indonesia sebesar 0,29\% dari tahun 2015 .

Disisi lain konsumsi pisang di Indonesia dari tahun 2011 sampai tahun 2016 mengalami fluktuasi dengan konsumsi tertinggi mencapai 2,14 juta ton dan konsumsi terendah mencapai 1,40 juta ton. Ketidakseimbangan antara produksi dengan konsumsi disebabkan oleh adanya permintaan akan kebutuhan ekspor serta beragamnya selera masyarakat dalam memilih dan mengonsumsi berbagai jenis buah-buahan lainnya (Kementerian Pertanian 2017).

Indonesia memiliki 34 provinsi yang tersebar di beberapa pulau dan potensial sebagai produsen buah pisang nasional untuk semua varietas pisang yang ada di Indonesia. Indonesia sebagai negara penghasil buah pisang memiliki berbagai varietas lokal pisang, seperti: Pisang Ambon, Pisang Raja Sereh, Pisang Kepok, Pisang Emas, dan juga varietas pisang nonlokal, seperti Pisang Cavendish. Provinsi Lampung sebagai bagian dari Indonesia berada padaposisi tertinggi kedua di Indonesia $(1.517,005$ ton), setelah Provinsi Jawa Timur (1.865.772 ton) (Kementerian Pertanian 2017).

Provinsi Lampung sebagai provinsi sentra produsen buah pisang kedua di Indonesia memiliki 15 kabupaten/kota. Kabupaten Pesawaran merupakan produsen buah pisang terbesar di Provinsi Lampung dengan produksi mencapai 626.264 ton atau 41,28 persen dari total produksi buah pisang di Provinsi Lampung (Kementerian Pertanian 2017).

Potensi konsumsi pisang di Provinsi Lampung dapat ditunjukkan melalui pendekatan data penduduk Provinsi Lampung per kabupaten/kota, yang diasumsikan sebagai konsumen yang potensial. Pada data penduduk ditunjukkan Kabupaten Lampung Tengah memiliki jumlah penduduk tertinggi di Provinsi Lampung dan dilanjutkan Kabupaten Lampung Timur pada posisi kedua serta Kota Bandar Lampung pada posisi ketiga. Meskipun Bandar Lampung masuk nomor urut tiga dari jumlah penduduk di Provinsi 
Lampung, tetapi penelitian ini dilakukan di Kota Bandar Lampung dengan alasan Kota Bandar Lampung merupakan ibukota dan pusat perekonomian Provinsi Lampung serta diasumsikan memiliki konsumen aktif yang lebih banyak dibandingkan daerah lainnya.

Penilaian puas atau tidak puas merupakan dampak dari perbandingan antara harapan konsumen sebelum melakukan pembelian produk dengan apa yang diperoleh konsumen dari produk yang dibeli. Pembelian Pisang Raja Sereh dan Pisang Cavendish yang dilakukan di dua tempat yang berbeda (pasar tradisional dan pasar modern) memungkinkan adanya perbedaan respon konsumen terhadap kepuasan dan loyalitas pada produk pisang, sehingga untuk menganalisis lebihjauh maka dilakukan penelitian upaya mengetahui kepuasan dan loyalitas konsumen terhadap Pisang Raja Sereh dan Pisang Cavendish di Kota Bandar Lampung.Berdasarkan uraian tersebut, maka penelitian ini memiliki tujuan: menganalisis kepuasan konsumen terhadap pembelian buah Pisang Raja Sereh dan Pisang Cavendish di pasar tradisional dan pasar modern (swalayan) Kota Bandar Lampung dan menganalisis loyalitas konsumen terhadap buah Pisang Raja Sereh dan Pisang Cavendish di pasar tradisional dan pasar modern (swalayan) di Kota Bandar Lampung.

\section{METODE PENELITIAN}

Metode yang digunakan dalam penelitian ini adalah metode survei. Penelitian ini dilaksanakan di dua tempat, yaitu: pasar tradisional Pasir Gintung dan pasar modern (swalayan) Gelael. Penentuan lokasi penelitian dilakukan secara sengaja (purposive) dengan pertimbangan bahwa Pasar Gintung dan Gelael memiliki lokasi yang cukup strategis, dekat dengan pusat keramaian kota dan lebih banyak dikunjungi oleh masyarakat Kota Bandar Lampung, serta memiliki keragaman jenis produk pisang yang didagangkan.

Sampel yang digunakan dalam penelitian ini adalah konsumen yang melakukan pembelian Pisang Raja Sereh dan Pisang Cavendish untuk dikonsumsi sendiri dan tidak untuk dijual kembali. Teknik penarikan sampel menggunakan non probability sampling,yaitu metode sampling yang tidak memberi kesempatan atau peluang yang sama bagi setiap unsur atau anggota populasi untuk dipilih menjadi sampel (Sugiyono 2009). Jenis non probability sampling yang digunakan adalah accidentialsampling, yaitu teknik pengambilan berdasarkan siapa saja yang memiliki kriteria yang cocok untuk diambil sebagai sampel (Sugiyono 2009). Sampel dalam penelitian ini sekaligus juga menjadi responden. Jumlah total responden yang digunakan dalam penelitian ini adalah 80 orang, yang dibagi menjadi 40 orang responden pada pasar tradisional (Pasar Pasir Gintung) dan 40 orang responden pada pasar modern (Gelael), hal ini mengacu pada Gay dan Diehl (1992) yang mengatakan bahwa ukuran sampel penelitian lebih baik lebih dari 30 orang.

Pengumpulan data penelitian dilakukan dengan menggunakan kueisioner dan wawancara langsung. Untuk mengukur atribut-atribut kuesioner kepuasan dan loyalitas maka dilakukan uji validitas dan reliabilitas menggunakan cronbach alpha, sehingga diperoleh atribut-atribut: harga, rasa, pelayanan, ketersediaan, ukuran, pengetahuan, kematangan, tekstur, rekomendasi, dan lokasi.

Waktu pengumpulan data penelitian adalahbulan Juni-Juli 2018. Jenis data yang dikumpulkan adalah data primer dan data sekunder. Data primer diperoleh secara langsung dari responden melalui wawancara dengan alat bantu kuesioner. Data sekunder diperoleh dari literatur/dokumen/arsip yang relevan serta lembaga/institusi yang berkaitan dengan penelitian ini.

Metode yang digunakan untuk menganalisis kepuasan konsumen adalah metode Customer Satisfaction Index (CSI) dan untuk menganalisis loyalitas konsumen adalah piramida loyalitas.

\section{Analisis Kepuasan Konsumen}

ConsumerSatisfactionIndex (CSI) adalah sebuah angka yang menyatakan seberapa besar kepuasan konsumen atas produk tertentu. CSI digunakan untuk mengetahui kepuasan pelanggan secara keseluruhan dengan memperhatikan tingkat kepentingan dari atribut-atribut suatu produk atau jasa. Nilai maksimum untuk CSI adalah 100 persen dengan rentang nilai menurut Uluum (2007) adalah sangat puas $(81 \%-100 \%)$, puas $(66 \%-80 \%)$, cukup puas $(51 \%-65 \%)$, kurang puas $(35 \%-50 \%)$, dan tidak puas (0\%-34\%). Tahapan-tahapan pengukuran CSI adalah (Santoso 2006):

a. Menghitung Weighting Factor (WF), dengan rumus:

Weight factor $=\frac{\text { RSP }}{\text { Total RSP }} \times 100 \%$ 
b. Menghitung Weighted Score (WS), dengan rumus:

Weighted Score $=$ RSK x WF

c. Menghitung Weighted Total (WT), dengan rumus:

Weighted Total $=$ Menjumlahkan semua WS.

d. Menghitung Indeks Kepuasan Konsumen, dengan rumus:

$\mathrm{CSI}=\frac{\mathrm{WT}}{\mathrm{HS}} \times 100 \%$

$\begin{aligned} & \text { Keterangan }= \text { RSP }=\text { Rataan skor kepentingan, } \\ & \text { RSK }=\text { Rataan skor kineja, }\end{aligned}$

$\mathrm{HS}=$ Highest Scale

2. Analisis Loyalitas Konsumen

Analisis loyalitas konsumen dilakukan dengan menggunakan piramida loyalitas. Piramida loyalitas terdiri dari switcher buyer, habitual buyer, satisfied buyer, liking the brand, dan committed buyer. Penggunaan rentang skala pada masing-masing tingkatan loyalitas digunakan untuk mengetahuikategorirentang skala yang digolongkan ke dalam lima golongan yang mengacu pada Durianto, Sugiarto, dan Toni (2004), yaitu: sangat jelek, jelek, cukup, baik, sangat baik. Rumus rentang skala yang digunakan adalah (Durianto, Sugiarto, dan Sitinjak 2004):

interval $=\frac{\text { nilai tertinggi }- \text { nilai terendah }}{\text { banyaknya kelas }}$.

Data tingkatan loyalitas konsumen merupakan data ordinal, maka dilakukan trasnformasi data dengan Method Successive Interval (MSI) dengan merubah nilai bobot jawaban (x) menjadi data interval.

\section{HASIL DAN PEMBAHASAN}

\section{Karakteristik Responden}

\section{a. Responden Pisang Raja Sereh}

Responden yang dipilih untuk Pisang Raja Serehberjumlah 40 orang yang diambil dari Pasar Pasir Gintung dan Gelael, yaitu konsumen yang telah melakukan pembelian pisang lebih dari satu kali dan melakukan pembelian pisang untuk dikonsumsi pribadi, karakteristiknya seperti disajikan pada Tabel 1.
Tabel 1. Karakteristik konsumen Pisang Raja Sereh di Pasar Gintung dan Gelael Bandar Lampung, tahun 2018

\begin{tabular}{|c|c|c|c|c|c|}
\hline \multirow[b]{2}{*}{ No. } & \multirow{2}{*}{$\begin{array}{l}\text { Karakteristik } \\
\text { Responden }\end{array}$} & \multicolumn{3}{|c|}{ Jumlah (orang) } & \multirow[b]{2}{*}{$\%$} \\
\hline & & $\begin{array}{c}\text { Pasir } \\
\text { Gintung }\end{array}$ & Gelael & Total & \\
\hline \multirow[t]{3}{*}{1.} & Jenis Kelamin: & & & & \\
\hline & -Wanita & 19 & 16 & 35 & 87,5 \\
\hline & -Pria & 1 & 4 & 5 & 12,5 \\
\hline \multirow[t]{5}{*}{2.} & Jenis Pekerjaan: & & & & \\
\hline & -PNS & 4 & 4 & 8 & 20,00 \\
\hline & -Wiraswasta & 5 & 5 & 10 & 25,0 \\
\hline & -Swasta & 2 & 5 & 7 & 17,5 \\
\hline & -IRT & 9 & 6 & 15 & 37,5 \\
\hline \multirow[t]{5}{*}{3.} & Pendidikan: & & & & \\
\hline & $-\mathrm{S} 2$ & 3 & 2 & 5 & 12,5 \\
\hline & $-\mathrm{S} 1$ & 9 & 10 & 19 & 47,5 \\
\hline & $-\mathrm{D} 3$ & 2 & 3 & 5 & 12,5 \\
\hline & -SLA & 6 & 5 & 11 & 27,5 \\
\hline \multirow[t]{5}{*}{4.} & Rentang umur *) & & & & \\
\hline & $-26-35$ & 2 & 5 & 7 & 17,5 \\
\hline & $-36-45$ & 6 & 5 & 11 & 27,5 \\
\hline & $-46-55$ & 11 & 7 & 18 & 45,0 \\
\hline & $-56-65$ & 1 & 3 & 4 & 10,0 \\
\hline
\end{tabular}

Keterangan *) pengelompokan mengacu pada

Departemen Kesehatan, tahun 2009

Berdasarkan Tabel 1 diketahui bahwa responden Pisang Raja Sereh di Pasar Pasir Gintung dan Gelael sebagian besar berjenis kelamin wanita (87,5\%), dengan pekerjaan ibu rumah tangga $(37,5 \%)$, dan tingkat pendidikan S1 $(47,5 \%)$, serta rentang umur didominasi $46-55$ tahun $(45,0 \%)$. Jenis kelamin wanita mendominasi konsumen Pisang Raja Sereh karena wanita memiliki peran besar dalam kegiatan berbelanja untuk memenuhi kebutuhan rumah tangga. Rentang umur responden Pisang Raja Sereh berada pada fase verilitas, yaitu masa persiapan usia lanjut, yang menampakkan keperkasaan fisik dan kematangan jiwa (Madani 2001).

\section{b. Responden Pisang Cavendish}

Karakteristik responden Pisang Cavendish dalam penelitian ini secara rinci dapat dilihat pada Tabel 2. Berdasarkan Tabel 2 diketahui bahwa karakteristik responden Pisang Cavendish di Pasar Pasir Gintung dan Gelael didominasi oleh jenis kelamin wanita $(95,0 \%)$, dengan pekerjaan ibu rumah tangga $(42,5 \%)$, dan tingkat pendidikan Sekolah Lanjut Atas (SLA) (42,5\%), serta rentang umur didominasi $36-45$ tahun $(57,5 \%)$. Jenis kelamin wanita juga mendominasi konsumen Pisang Cavendish karenawanita memiliki peran besar dalam kegiatan berbelanja untuk memenuhi kebutuhan rumah tangga. Rentang umur responden Pisang Cavendish berada pada fase iuventus, yaitu 
Tabel 2. Karakteristik konsumen Pisang Cavendish di Pasar Pasir Gintung dan Gelael Bandar Lampung, tahun 2018

\begin{tabular}{|c|c|c|c|c|c|}
\hline \multirow[b]{2}{*}{ No. } & \multirow{2}{*}{$\begin{array}{c}\text { Karakteristik } \\
\text { Responden }\end{array}$} & \multicolumn{3}{|c|}{ Jumlah (orang) } & \multirow[b]{2}{*}{$\%$} \\
\hline & & $\begin{array}{c}\text { Pasir } \\
\text { Gintung }\end{array}$ & Gelael & Total & \\
\hline \multirow[t]{3}{*}{1.} & Jenis Kelamin: & & & & \\
\hline & -Wanita & 19 & 19 & 38 & 95,0 \\
\hline & -Pria & 1 & 1 & 2 & 5,0 \\
\hline \multirow{5}{*}{2.} & Jenis Pekerjaan: & & & & \\
\hline & -PNS & 5 & 3 & 8 & 20,0 \\
\hline & -Wiraswasta & 4 & 8 & 12 & 30,0 \\
\hline & -Swasta & 0 & 3 & 3 & 7,5 \\
\hline & -IRT & 11 & 6 & 17 & 42,5 \\
\hline \multirow[t]{5}{*}{3.} & Pendidikan: & & & & \\
\hline & $-\mathrm{S} 2$ & 4 & 1 & 5 & 12,5 \\
\hline & $-\mathrm{S} 1$ & 5 & 7 & 12 & 30,00 \\
\hline & -D3 & 3 & 3 & 6 & 15,0 \\
\hline & -SLA & 8 & 9 & 17 & 42,5 \\
\hline \multirow[t]{5}{*}{4.} & Rentang umur $*$ ) & & & & \\
\hline & $-26-35$ & 1 & 2 & 3 & 7,5 \\
\hline & $-36-45$ & 10 & 13 & 23 & 57,5 \\
\hline & $-46-55$ & 9 & 4 & 13 & 32,5 \\
\hline & $-56-65$ & 0 & 1 & 1 & 2,5 \\
\hline
\end{tabular}

Keterangan *) pengelompokan mengacu pada

Departemen Kesehatan, tahun 2009

masa umur dewasa berlangsung dan memiliki keinginan terhadap hal baru yang cukup tinggi.

\section{Kepuasan Konsumen}

\section{a. Kepuasan konsumen Pisang Raja Sereh}

Kepuasan konsumen Pisang Raja Sereh diukur dengan menghitung nilai pada atribut tingkat kepentingan dan nilai atribut tingkat kinerja. Pengukuran diperlukan untuk mengetahui besarnya indeks kepuasan konsumen (CSI) responden Pisang Raja Sereh Pasar Pasir Gintung dan Gelael.

Data pada Tabel 3 menunjukkan hasil perhitungan kepuasan konsumen (CSI) Pisang Raja Sereh yang terdiri dari 10 atribut kepentingan dan kinerja konsumen, yaitu harga, rasa, pelayanan, ketersediaan, ukuran, pengetahuan, tingkat kematangan, tekstur, rekomendasi, dan lokasi penjualan yang disimbolkan dengan P1-P10 dan K1-K10. Kepuasan konsumen (CSI) Pisang Raja Serehadalah sebesar 74,66 persen, nilai tersebut berada pada kategori "puas" (66\%-80\%), artinya konsumen telah puas terhadap produk Pisang Raja Sereh yang dilihat dari 10 atribut kepuasan konsumen. Hasil analisis kepuasan konsumen secara lengkap disajikan pada Tabel 3. Atribut kepentingan tertinggi didapat pada atribut P3 (pelayanan) dan untuk atribut kinerja pada atribut K7 (kematangan). Konsumen Pisang Raja Sereh lebih mementingkan terhadap segi pelayanan yang memiliki kinerja dilapangan lebih rendah dari yang diharapkan, dan untuk tingkat kematangan pada kinerja di lapangan memiliki nilai lebih rendah dari yang harapkan konsumen Pisang Raja Sereh.

\section{b. Kepuasan konsumen Pisang Cavendish}

Hasil analisis kepuasan konsumen terhadap Pisang Cavendish disajikan pada Tabel 4. Tabel 4 menunjukkan hasil perhitungan kepuasan konsumen (CSI) Pisang Cavendish yang terdiri dari penggunaan 10 atribut kepentingan dan kinerja konsumen, yaitu harga, rasa, pelayanan, ketersediaan, ukuran, pengetahuan, tingkat kematangan, tekstur, rekomendasi, dan lokasi penjualan yang disimbolkan dengan P1-P10 dan K1-K10. Pada Tabel 4 terlihat bahwa nilai kepuasan konsumen (CSI) Pisang Cavendish adalah 71,09 persen dan terletak pada rentang skala $(66 \%$ - 80\%) kategori "puas", dan dapat dinyatakan bahwa konsumen "puas" terhadap Pisang Cavendish.

Bila diperhatikan hasil CSI Pisang Raja Sereh dan Pisang Cavendish, maka dapat dinyatakan bahwa keduanya berada pada rentang skala yang sama"puas" (66\% - 80\%). Pisang Raja Sereh memiliki nilai CSI yang lebih besar $(74,66 \%)$ dibandingkan dengan Pisang Cavendish $(71,09 \%)$. Untuk meningkatkan kepuasan konsumen terhadap Pisang Cavendish, maka Pasar Pasir Gintung dan

Tabel 3. Hasil perhitungan kepuasan konsumen (CSI) terhadap Pisang Raja Sereh di Pasar Pasir Gintung dan Gelael Bandar Lampung, tahun 2018

\begin{tabular}{|c|c|c|c|c|c|c|}
\hline No & Kepentingan & RSP & $\begin{array}{l}\text { WF } \\
(\%)\end{array}$ & Kinerja & RSK & WS \\
\hline 1 & P1 *) & 4,45 & 10,84 & $\mathrm{~K} 1 *)$ & 3,65 & 0,40 \\
\hline 2 & $\mathrm{P} 2$ & 4,48 & 10,91 & $\mathrm{~K} 2$ & 3,88 & 0,42 \\
\hline 3 & P3 & 4,68 & 11,40 & K3 & 3,88 & 0,44 \\
\hline 4 & $\mathrm{P} 4$ & 4,05 & 9,86 & K4 & 3,88 & 0,38 \\
\hline 5 & P5 & 3,98 & 9,69 & K5 & 3,58 & 0,35 \\
\hline 6 & P6 & 4,13 & 10,06 & K6 & 3,80 & 0,38 \\
\hline 7 & P7 & 4,03 & 9,81 & K7 & 3,95 & 0,39 \\
\hline 8 & P8 & 4,03 & 9,81 & K8 & 3,50 & 0,34 \\
\hline 9 & P9 & 3,38 & 8,23 & K9 & 3,50 & 0,29 \\
\hline \multirow[t]{4}{*}{10} & P10 & 3,85 & 9,38 & $\mathrm{~K} 10$ & 3,63 & 0,34 \\
\hline & Jumlah & 41,06 & & & & \\
\hline & $\begin{array}{l}\text { Weight Total } \\
\text { (WT) }\end{array}$ & & & & & 3,73 \\
\hline & CSI & & & & $66 \%$ & \\
\hline
\end{tabular}

*Keterangan: P1-P10= Atribut Kepentingan,

$\begin{array}{ll}\text { K1-K10 } & \text { Atribut Kinerja } \\ \text { RSP } & =\text { Rata-rata skor kepentingan } \\ \text { RSK } & =\text { Rata-rata skor kinerja } \\ \text { WF } & =\text { Weight factor } \\ \text { WS } & =\text { Weight score }\end{array}$


Gelael harus mempertahankan bahkan meningkatkan kualitas Pisang Cavendish yang dipasarkan agar konsumen tetap merasa puas bahkan sangat puas dengan cara melakukan pengawasan terhadap kelayakan jual pisang.

Hasil perhitungan kepuasan konsumen (CSI) terhadap Pisang Raja Sereh dan Pisang Cavendish pada penelitian ini selaras dengan penelitian Permadi (2015) yang berjudul "Analisis Kepuasan Konsumen Terhadap Atribut Buah Pisang Kepok", yaitu konsumen merasa puas terhadap kinerja produk pisang tersebut dan berada pada skala $(66 \%$ - 80\%) kategori "puas". Penelitian ini juga sejalan dengan penelitian Wardika, Dewi, dan Artini (2018) dengan judul "Analisis Kepuasan Pelanggan dalam Membeli Buah-buahan Segar di Moena Fresh Bali", yaitu konsumen juga merasa puas terhadap kinerja produk buah-buahan dan berada pada rentang skala $(66 \%-80 \%)$ kategori "puas".

Atribut kepentingan tertinggi didapat pada atribut P3 (pelayanan) dan untuk atribut kinerja pada atribut K2 (rasa). Konsumen Pisang Raja Sereh lebih mementingkan terhadap segi pelayanan yang memiliki kinerja dilapangan lebih rendah dari yang diharapkan, dan untuk atribut rasa pada kinerja di lapangan memiliki nilai lebih rendah dari yang diharapkan konsumen Pisang Cavendish.

Tabel 4. Hasil perhitungan kepuasankonsumen (CSI) terhadap Pisang Cavendish di Pasar Pasir Gintung dan Gelael Bandar Lampung, tahun 2018

\begin{tabular}{llrrlcc}
\hline $\begin{array}{ll}\text { N } \\
\text { o }\end{array}$ & Kepentingan & RSP & $\begin{array}{c}\text { WF } \\
(\%)\end{array}$ & $\begin{array}{c}\text { Kinerj } \\
\text { a }\end{array}$ & RSK & WS \\
\hline 1 & P1 *) & 4,28 & 10,85 & K1 $\left.{ }^{*}\right)$ & 3,35 & 0,36 \\
2 & P2 & 4,28 & 10,85 & K2 & 3,90 & 0,42 \\
3 & P3 & 4,63 & 11,74 & K3 & 3,70 & 0,43 \\
4 & P4 & 3,88 & 9,84 & K4 & 3,80 & 0,37 \\
5 & P5 & 3,63 & 9,20 & K5 & 3,65 & 0,34 \\
6 & P6 & 4,08 & 10,34 & K6 & 3,48 & 0,36 \\
7 & P7 & 3,90 & 9,89 & K7 & 3,73 & 0,37 \\
8 & P8 & 3,95 & 10,02 & K8 & 3,20 & 0,32 \\
9 & P9 & 3,30 & 8,36 & K9 & 3,28 & 0,27 \\
1 & P10 & 3,53 & 8,95 & K10 & 3,35 & 0,30 \\
0 & & & & & & \\
\hline
\end{tabular}

\begin{tabular}{lll} 
Jumlah & 39,46 & \\
\hline \multicolumn{3}{l}{ Weight Total } \\
(WT)
\end{tabular}

\section{Loyalitas Konsumen}

\section{a. Loyalitas konsumen Pisang Raja Sereh}

Loyalitas konsumen terhadap Pisang Raja Sereh dinilai atas dasar kriteria tingkatan loyalitas konsumen yang terdiri dari: switcher buyer, habitual buyer, satisfied buyer, liking the brand, dan committed buyer dalam piramida loyalitas.

\section{Switcher buyer Pisang Raja Sereh}

Hasil perhitungan switcher buyer Pisang Raja Serehsebesar43 persen, artinya konsumen yang beralih ke produk lain karena perubahan harga sebesar 43 persen, dan hasil rata-rata skor switcher buyer Pisang Raja Sereh adalah 2,01dan nilai tersebut berada pada rentang skala 1,62 - 2,42 (kategori "cukup" sensitif terhadap perubahan harga).

\section{Habitual buyer Pisang Raja Sereh}

Hasil perhitungan habitual buyer Pisang Raja Serehsebesar 83 persen, artinya konsumen yang membeli Pisang Raja Sereh karena kebiasaan sebesar 83 persen dan rata-rata skorhabitual buyer didapat 2,75 dan termasuk dalam kategori "baik" (rentang skala 2,55 - 3,3), sehingga dapat dinyatakan bahwa konsumen membeli Pisang Raja Sereh karena kebiasaan.

\section{Satisfied buyerPisang Raja Sereh}

Hasil perhitungansatsified buyer Pisang Raja Sereh sebesar 90 persen, artinya konsumen yang puas terhadap Pisang Raja Sereh adalah 90 persen. Rata-rata skor satisfied buyer Pisang Raja Serehsebesar 2,75 (berada pada rentang skala 2,43 - 3,23) dengan kategori "baik", sehingga konsumen dinyatakan "puas" terhadap konsumsi Pisang Raja Sereh.

\section{Liking the brand Pisang Raja Sereh}

Hasil perhitungan liking the brand Pisang Raja Sereh didapat sebesar 90 persen, artinya konsumen yang membeli Pisang Raja Sereh karena kesukaan adalah 90 persen, dan rata-rata skor liking the brand adalah sebesar 2,75 (berada dalam kategori "baik"dengan rentang skala 2,19-2,91), sehingga dapat dinyatakan bahwa konsumen membeli Pisang Raja Sereh karena suka. 


\section{Commited buyer Pisang Raja Sereh}

Committed buyer adalah konsumen yang yang membeli buah Pisang Raja Sereh sebagai pelanggan yang setia. Golongan pembeli yang loyal terhadap Pisang Raja Sereh sebanyak 85 persen. Hasil rata-rata skor commited buyer2,55 (berada pada rentang skala 2,37 - 3,15 dengan kategori "baik"), sehingga dapat dinyatakan bahwa konsumen bersedia untuk menyarankan dan mempromosikan Pisang Raja Sereh kepada orang lain.

Setelah dilakukan perhitungan terhadap lima tingkatan loyalitas, maka dapat dirangkum ke dalam piramida loyalitas konsumen. Hasil piramida loyalitas konsumen terhadap Pisang Raja Sereh disajikan pada Gambar 1. Berdasarkan Gambar 1 dapat diketahui bahwa loyalitas konsumen terhadap Pisang Raja Serehsudah pada tahap pembeli yang loyal.

Nilai commited buyer didapat lebih besar dibandingkan nilai switcher buyer walaupun masih didominasi nilai liking the brand (90\%) dan Satisfied Buyer (90\%).Committed buyer merupakan kategori responden yang akan merekomendasikan dan mempromosikan produk kepada orang lain, seperti dinyatakan oleh Liang dan Zhang (2011), bahwa indikator utama dari loyalitas adalah rekomendasi kepada orang lain, menyediakan informasi positif word of mouth, dan setia.

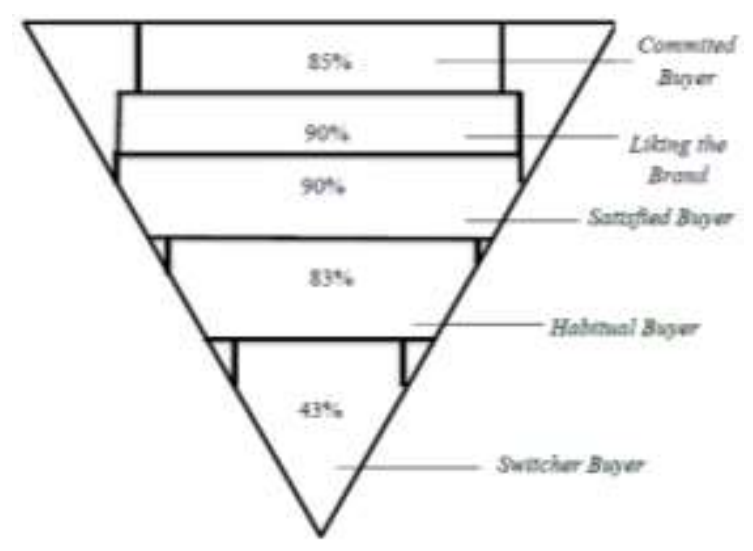

Gambar 1. Piramida loyalitas konsumen terhadap Pisang Raja Sereh di Pasar Pasir Gintung dan Gelael Bandar Lampung, tahun 2018

\section{b. Loyalitas Konsumen terhadap Pisang Cavendish}

Pada penelitian ini, loyalitas konsumen terhadap Pisang Cavendish dinilai berdasarkan kriteria tingkatan loyalitas yang terdiri dari switcher buyer, habitual buyer, satisfied buyer,liking the brand, dan committed buyer.

\section{Switcher Buyer Pisang Cavendish}

Hasil perhitungan Switcher Buyer terhadap Pisang Cavendish didapat nilai sebesar 55 persen, artinya konsumen yang peka terhadap perubahan harga adalah sebesar 55 persen, dan nilai rata-rata skor switcher buyer Pisang Cavendish adalah 2,40, (beradapada rentang skala 1,62 - 2,42 kategori "cukup" sensitif terhadap harga).

\section{Habitual buyer Pisang Cavendish}

Nilai habitual buyer Pisang Cavendish didapat sebesar 73 persen, artinya jumlah konsumen yang membeli pisang karena kebiasaan adalah 73 persen. Nilai rata-rata skor habitual buyer adalah 2,89, yang artinya klasifikasi habitual buyer berada dalam kategori "baik" (rentang nilai 2,73 - 3,63), sehingga konsumen penelitian ini membeli Pisang Cavendish karena sudah kebiasaan.

\section{Satisfied buyer Pisang Cavendish}

Nilai satsified buyer Pisang Cavendish didapat 93 persen, artinya konsumen yang puas terhadap Pisang Cavendish sebesar 93 persen. Nilai ratarata skor satisfied buyer adalah 2,89 dan berada pada rentang nilai $2,73-3,63$ dengan kategori "baik".

\section{Liking the brand Pisang Cavendish}

Nilailiking the brand Pisang Cavendish didapat 80 persen, artinya konsumen yang membeli Pisang Cavendish karena suka sebesar 80 persen. Nilai rata-rata skor liking the brand konsumen adalah sebesar 2,40, artinya klasifikasi liking the brand berada dalam kategori "baik" (rentang skala 2,25 2,99), sehingga konsumen dinyatakan suka terhadap Pisang Cavendish dan memiliki pengalaman dalam mengkonsumsi Pisang Cavendish dan merasa terpenuhi kebutuhannya.

\section{Commited buyer Pisang Cavendish}

Nilai commited buyer Pisang Cavendish adalah 90 persen, artinya konsumen yang akan menyarankan 
dan mempromosikan Pisang Cavendish kepada orang lain adalah 90 persen. Nilai rata-rata skor commited buyer didapat sebesar 2,75 dan termasuk dalam rentang skala 1,92 - 2,87 dengan kategori "baik". Konsumen yang tergolong ke dalam commited buyer mengaku merasa percaya diri telah mengonsumsi Pisang Cavendish dan bersedia untuk merekomendasikan produk Pisang Cavendish kepada orang lain.

Hasil perhitungan loyalitas konsumen terhadap Pisang Raja Sereh dan Pisang Cavendish pada penelitian ini selaras dengan penelitian Pradinata (2017) yang berjudul "Analisis Kepuasan dan Loyalitas Konsumen Kopi AAA di Kabupaten Kerinci" dimana konsumen Kopi AAA termasuk ke dalam konsumen yang "loyal". Hal ini dapat dilihat dari nilai commited buyer sebesar (68\%), liking the brand (68\%), satisfied buyer (70\%), habitual buyer (69\%) dan switcher buyer (57\%). Setelah semua tingkatan dari piramida loyalitas konsumen dihitung, maka dapat dimasukkan ke dalam piramida loyalitas Pisang Cavendish, seperti disajikan pada Gambar 2. Tingkatan commited buyer pada piramida loyalitas konsumen Pisang Cavendish memiliki nilai persentase yang tinggi (90\%), dengan nilai tersebut menunjukkan bahwa konsumen Pisang Cavendish sudah dikatakan loyal dengan pertimbangan bahwa nilai switcher buyer lebih rendah dibandingkan nilai pada commited buyer, sehingga ketika konsumen mencapai tingkat tersebut, maka tingkat perpindahan terhadap suatu produk akan sangat kecil.

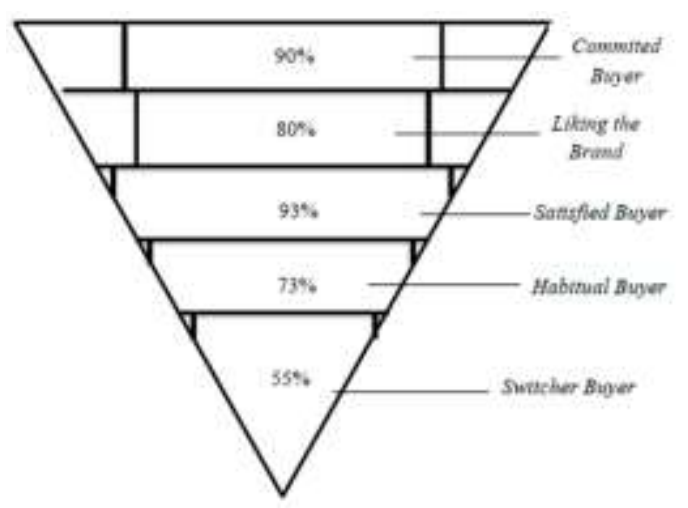

Gambar 2. Piramida loyalitas konsumen terhadap Pisang Cavendish di Pasar Pasir Gintung dan Gelael Bandar Lampung, tahun 2018
Bila dibandingkan Pisang Raja Sereh dan Pisang Cavendish, maka dapat dinyatakan bahwa konsumen Pisang Raja Sereh dan Pisang Cavendish sama-sama berada pada kategori loyal, walaupun konsumen Pisang Cavendish yang "commited" lebih banyak dibandingkan konsumen Pisang Raja Sereh. Namun demikian, konsumsi PisangRaja Sereh sudah menjadi kebiasaan (habit) dan disukai (liking) oleh konsumen. Piramida Pisang Cavendish juga belum dikatakan sempurna karena, hasil perhitungan commited buyer lebih kecil dibandingkan satisfied buyer, tetapi lebih besar dari liking the brand. Namun demikian, konsumsi Pisang Cavendish menimbulkan rasa puas (satisfied) dan mau merekomendasikan tanpa harus menyukai (liking).

Bila digabungkan indikator hasil uji kepuasan dan loyalitas konsumen terhadap Pisang Raja Serehdan Pisang Cavendish, maka dapat dinyatakan seperti disajikan pada Tabel 5. Data pada Tabel 5 menunjukkan bahwa hasil penilaian kepuasan konsumen Pisang Raja Sereh lebih besar dibandingkan Pisang Cavendish, dan nilai commited buyer Pisang Cavendish lebih besar dibandingkan Pisang Raja Sereh. Hasil tersebut seakan-akan tidak konsisten antara kepuasan konsumen dengan loyalitas konsumen, namun demikian secara keseluruhan kategori loyalitas konsumen Pisang Raja Sereh lebih unggul dibandingkan Pisang Cavendish, dengan kata lain konsumen Pisang Raja Sereh tidak merasa perlu lagi untuk merekomendasikan konsumsi Pisang Raja Serehkepada orang lain, dan produsen Pisang Raja Sereh juga tidak perlu merasa khawatir bahwa konsumsi Pisang Raja Sereh akan tergantikan oleh Pisang Cavendish.

Tabel 5. Gabungan indikator hasil uji kepuasan dan loyalitas konsumen Pisang Raja Sereh dan Pisang Cavendish di Kota Bandar Lampung, tahun 2018

\begin{tabular}{lcc}
\hline \multicolumn{1}{c}{ Keterangan } & $\begin{array}{c}\text { Pisang Raja } \\
\text { Sereh } \\
(\%)\end{array}$ & $\begin{array}{c}\text { Pisang } \\
\text { Cavendish } \\
(\%)\end{array}$ \\
\hline $\begin{array}{l}\text { Kepuasan:Consumer } \\
\text { Satsifaction Index (CSI) }\end{array}$ & 74,66 & 71,09 \\
\hline Loyalitas: & & \\
Commited buyer & 85,00 & 90,00 \\
Liking the brand & 90,00 & 80,00 \\
Satisfied buyer & 90,00 & 93,00 \\
Habitual buyer & 83,00 & 73,00 \\
Switcher buyer & 43,00 & 55,00 \\
\hline
\end{tabular}




\section{KESIMPULAN}

Konsumen Pisang Raja Serehdan Pisang Cavendish yang membeli pisang di Pasar Pasir Gintung dan Gelael termasuk ke dalam kategori "puas", walaupun nilai kepuasan (CSI) konsumen Pisang Raja Sereh lebih tinggi dibandingkan dengan Pisang Cavendish. Konsumen Pisang Raja Serehdan Pisang Cavendish sudah termasuk dalam kategori loyal (commited), walaupun nilai commited buyer Pisang Raja Sereh lebih kecil dari Pisang Cavendish.

\section{DAFTAR PUSTAKA}

Departemen Kesehatan. 2009. Profil Kesehatan Indonesia. Departemen Republik Indonesia. Jakarta.

Durianto D, Sugiarto, dan Sitinjak T. 2004. Strategi Menaklukkan Pasar Melalui Riset Ekuitas dan Perilaku Merek. PT Gramedia Pustaka Utama. Jakarta.

Gay LR dan Diehl PL. 1992. Research Methods for Business and Management. Mac Milan Publishing Company. New York.

Kementerian Pertanian. 2017. Produksi Pisang Menurut Provinsi 2012-2016. http://pertanian.go.id/ap_pages/mod/dataho rti. [17 Januari 2018]
Liang dan Zhang. 2011. The Effect of Service Interaction Orientation on Customer Satisfaction and Behavioral Intention: The Moderating Effect of Dining Frequency. Procedia Social and Behavioral Sciences Vol 24 1026-1035.

Madani J. 2001. Batasan Usia Dewasa. EGC. Jakarta.

Permadi R. 2015. Analisis Kepuasan KonsumenTerhadap Atribut Buah Pisang Kepok.JCEA, 4(2) 8-15. Jurnal.untan.ac.id/index.php/jsea/article/vi ew/12765/11569. [Oktober 2018]

Pradinata J. 2017. Analisis Kepuasan Dan Loyalitas Konsumen Kopi AAA Di Kabupaten Kerinci. AL-INFAQ: JEI, 8(2) 168-182. www.jurnalfaiuikabogor.org/index.php/alinfaq/article/do wnload/18/18. [Oktober 2018]

Santoso. 2006. Menggunakan SPPS untuk Statistik Non parametrik. PT Elex Media Komputindo. Jakarta.

Sugiyono. 2009. Metode Penelitian Kuantitatif, Kualitatif dan $R \& D$. Alfabeta. Bandung.

Uluum. 2007. Panduan Survei Kepuasan Konsumen. PT Sucofindo. Jakarta.

Wardika OP, Dewi KR, dan Artini PWN. 2018. Analisis Kepuasan Pelanggan Dalam Membeli Buah-Buahan SegarDi Moena Fresh Bali. JAA, 7(1) 81-90. http://ojs.unud.ac.id/index.php/JAA/article/ download/37005/22415. [Oktober 2018] 